\title{
Missing the Popular Vote: Pitfalls in US Democracy and Reform Proposals
}

\author{
Only a few years ago, it was a widespread belief that globalisation would trigger processes \\ of democratisation worldwide. However, even old and established democracies such as the \\ United States have recently revealed serious weaknesses. This article shows that the US \\ election system is heavily distorted and recommends profound and transparent Electoral \\ College reforms in the election of US presidents. Furthermore, the article highlights the \\ implications the challenges facing American democracy have for Europe.
}

Recall the clash between former United States Secretary of State, Colin Powell, and the French Minister of Foreign Affairs, Dominique de Villepin, at a session of the Security Council of the United Nations in February of 2003. Whereas de Villepin pointed at the long-lasting history of his country and the significance of the French revolution in 1789, Powell stressed the fact that the US may still be considered the oldest democracy in the (Western) world. These memories do match quite well with the actual desire of so many Americans to get back to what the people in the US had seized already centuries ago.

The United States is still an impressive democracy whose system of "checks and balances", its independent institutions (such as the Supreme Court), and loyal civil servants have helped save the country from the Trumpist attack. However, the US election system has recently revealed serious weaknesses. This applies not only to US presi-

(c) The Author(s) 2021. Open Access: This article is distributed under the terms of the Creative Commons Attribution 4.0 International License (https://creativecommons.org/licenses/by/4.0/).

Open Access funding provided by ZBW - Leibniz Information Centre for Economics.

Friedrich L. Sell, Bundeswehr University Munich, Neubiberg, Germany.

Jürgen Stiefl, Hochschule Aalen - Technik und Wirtschaft, Germany. dential elections, but to congressional elections as well. Though more complex in detail, election systems are built on the idea of winning the (preferably absolute) majority, but not necessarily the popular vote. Notice that combining the criteria "democracy" (direct vs. indirect) and the "right to vote" (majority principle vs. proportionality principle) yields four basic types of elections. The election of the US President is de facto an indirect one, organised under the rules of the majority principle. Members in the House of Representatives, conversely, are also appointed following the majority principle, but in a direct way.

The mentioned weaknesses can be identified easily: during the 2016 presidential election, Hillary Clinton was defeated by Donald Trump, although she won the "popular vote share" (percentage of votes gained on a national level) by three percentage points. At the same time, particularly since the beginning of the new millennium, "gerrymandering", a smart and at the same time manipulative technique to redesign the size and form of districts for the election of members of the House of Representatives, has had a significant upswing. This goes along with severe and negative consequences for the relevance of the popular vote: Again in 2016, 49.5\% of the popular vote in the state of Wisconsin elections for the House of Representatives went to the Democrats and only $45.9 \%$ went to Republicans. Regardless, the Republicans won five and Democrats won three out of the eight districts (Illinger et al., 2018). This means that Republicans won a seat share of $62.5 \%$ while Democrats won only $37.5 \%$. As these two remarkable events stick out in comparison to the recent elections in 2020, this article focuses on the 2016 episodes. 
Table 1

\section{Results of the presidential election of 2016}

\begin{tabular}{|c|c|c|c|c|c|}
\hline \multirow[b]{2}{*}{ States } & \multirow[b]{2}{*}{ Electors } & \multicolumn{2}{|c|}{ Absolute votes } & \multicolumn{2}{|c|}{ Vote share in $\%$} \\
\hline & & Clinton & Trump & Clinton & Trump \\
\hline Alabama & $9(\mathrm{R})$ & 729,547 & $1,318,255$ & 35.63 & 64.37 \\
\hline Alaska & $3(\mathrm{R})$ & 116,454 & 163,387 & 41.61 & 58.39 \\
\hline Arizona & $11(\mathrm{R})$ & $1,161,167$ & $1,252,401$ & 48.11 & 51.89 \\
\hline Arkansas & $6(\mathrm{R})$ & 380,494 & 684,872 & 35.71 & 64.29 \\
\hline California & $55(\mathrm{D})$ & $8,753,788$ & $4,483,810$ & 66.13 & 33.87 \\
\hline Colorado & $9(\mathrm{D})$ & $1,338,870$ & $1,202,484$ & 52.68 & 47.32 \\
\hline Connecticut & 7 (D) & 897,524 & 673,197 & 57.14 & 42.86 \\
\hline Delaware & $3(\mathrm{D})$ & 235,603 & 185,127 & 56.00 & 44.00 \\
\hline District of Columbia & $3(\mathrm{D})$ & 282,830 & 12,723 & 95.70 & 4.30 \\
\hline Florida & $29(\mathrm{R})$ & $4,504,975$ & $4,617,886$ & 49.38 & 50.62 \\
\hline Georgia & $16(\mathrm{R})$ & $1,877,963$ & $2,089,104$ & 47.34 & 52.66 \\
\hline Hawaii & $3(D)$ & 266,891 & 128,847 & 67.44 & 32.56 \\
\hline Idaho & $4(\mathrm{R})$ & 189,765 & 409,055 & 31.69 & 68.31 \\
\hline Illinois & $20(D)$ & $3,090,729$ & $2,146,015$ & 59.02 & 40.98 \\
\hline Indiana & $11(\mathrm{R})$ & $1,039,126$ & $1,557,286$ & 40.02 & 59.98 \\
\hline lowa & $6(\mathrm{R})$ & 653,669 & 800,983 & 44.94 & 55.06 \\
\hline Kansas & $6(\mathrm{R})$ & 427,005 & 671,018 & 38.89 & 61.11 \\
\hline Kentucky & $8(\mathrm{R})$ & 628,854 & $1,202,971$ & 34.33 & 65.67 \\
\hline Louisiana & $8(\mathrm{R})$ & 780,154 & $1,178,638$ & 39.83 & 60.17 \\
\hline Maine & $3(\mathrm{D}) / 1(\mathrm{R})$ & 357,735 & 335,593 & 51.60 & 48.40 \\
\hline Maryland & $10(\mathrm{D})$ & $1,677,928$ & 943,169 & 64.02 & 35.98 \\
\hline Massachusetts & $11(\mathrm{D})$ & $1,995,196$ & $1,090,893$ & 64.65 & 35.35 \\
\hline Michigan & $16(\mathrm{R})$ & $2,268,839$ & $2,279,543$ & 49.88 & 50.12 \\
\hline Minnesota & $10(\mathrm{D})$ & $1,367,716$ & $1,322,951$ & 50.83 & 49.17 \\
\hline Mississippi & $6(\mathrm{R})$ & 485,131 & 700,714 & 40.91 & 59.09 \\
\hline Missouri & $10(\mathrm{R})$ & $1,071,068$ & $1,594,511$ & 40.18 & 59.82 \\
\hline Montana & $3(\mathrm{R})$ & 177,709 & 279,240 & 38.89 & 61.11 \\
\hline Nebraska & $5(\mathrm{R})$ & 284,494 & 495,961 & 36.45 & 63.55 \\
\hline Nevada & $6(\mathrm{D})$ & 539,260 & 512,058 & 51.29 & 48.71 \\
\hline New Hampshire & $4(\mathrm{D})$ & 348,526 & 345,790 & 50.20 & 49.80 \\
\hline New Jersey & $14(\mathrm{D})$ & $2,148,278$ & $1,601,933$ & 57.28 & 42.72 \\
\hline New Mexico & $5(\mathrm{D})$ & 385,234 & 319,666 & 54.65 & 45.35 \\
\hline New York & 29 (D) & $4,491,191$ & $2,790,073$ & 61.68 & 38.32 \\
\hline North Carolina & $15(\mathrm{R})$ & $2,189,322$ & $2,362,632$ & 48.10 & 51.90 \\
\hline North Dakota & $3(\mathrm{R})$ & 93,758 & 216,794 & 30.19 & 69.81 \\
\hline Ohio & $18(\mathrm{R})$ & $2,394,164$ & $2,841,005$ & 45.73 & 54.27 \\
\hline Oklahoma & $7(\mathrm{R})$ & 420,375 & 949,136 & 30.70 & 69.30 \\
\hline Oregon & $7(\mathrm{D})$ & $1,001,964$ & 782,269 & 56.16 & 43.84 \\
\hline Pennsylvania & $20(\mathrm{R})$ & $2,926,441$ & $2,970,733$ & 49.62 & 50.38 \\
\hline Rhode Island & $4(\mathrm{D})$ & 252,525 & 180,543 & 58.31 & 41.69 \\
\hline South Carolina & $9(\mathrm{R})$ & 855,373 & $1,155,389$ & 42.54 & 57.46 \\
\hline South Dakota & $3(R)$ & 117,458 & 227,721 & 34.03 & 65.97 \\
\hline Tennessee & $11(\mathrm{R})$ & 870,695 & $1,522,925$ & 36.38 & 63.62 \\
\hline Texas & $36(\mathrm{R})$ & $3,877,868$ & $4,685,047$ & 45.29 & 54.71 \\
\hline Utah & $6(\mathrm{R})$ & 310,676 & 515,231 & 37.62 & 62.38 \\
\hline Vermont & $3(\mathrm{D})$ & 178,573 & 95,369 & 65.19 & 34.81 \\
\hline Virginia & $13(D)$ & $1,981,473$ & $1,769,443$ & 52.83 & 47.17 \\
\hline Washington & $8(\mathrm{D})$ & $1,742,718$ & $1,221,747$ & 58.79 & 41.21 \\
\hline West Virgina & $5(\mathrm{R})$ & 188,794 & 489,371 & 27.84 & 72.16 \\
\hline Wisconsin & $10(\mathrm{R})$ & $1,382,536$ & $1,405,284$ & 49.59 & 50.41 \\
\hline \multirow[t]{2}{*}{ Wyoming } & $3(\mathrm{R})$ & 55,973 & 174,419 & 24.29 & 75.71 \\
\hline & & $65,794,399$ & $62,955,212$ & & \\
\hline
\end{tabular}

Note: (R) stands for the Republican Party and (D) for the Democratic Party. Source: National Archives (2020). 
Table 2

Partial results of the presidential election of 2016: Majority principle vs. proportionality principle

\begin{tabular}{|c|c|c|c|c|c|c|c|}
\hline \multirow[b]{2}{*}{ States } & \multirow[b]{2}{*}{ Electors } & \multicolumn{2}{|c|}{ Absolute votes } & \multicolumn{2}{|c|}{ Vote share in \% } & \multicolumn{2}{|c|}{ Proportionality principle } \\
\hline & & Clinton & Trump & Clinton & Trump & Clinton & Trump \\
\hline Arizona & $11(\mathrm{R})$ & $1,161,167$ & $1,252,401$ & 48.11 & 51.89 & 5 & 6 \\
\hline Florida & $29(\mathrm{R})$ & $4,504,975$ & $4,617,886$ & 49.38 & 50.62 & 14 & 15 \\
\hline Michigan & $16(\mathrm{R})$ & $2,268,839$ & $2,279,543$ & 49.88 & 50.12 & 8 & 8 \\
\hline Minnesota & $10(\mathrm{D})$ & $1,367,716$ & $1,322,951$ & 50.83 & 49.17 & 5 & 5 \\
\hline Nevada & $6(\mathrm{D})$ & 539,260 & 512,058 & 51.29 & 48.71 & 3 & 3 \\
\hline New Hampshire & $4(\mathrm{D})$ & 348,526 & 345,790 & 50.20 & 49.80 & 2 & 2 \\
\hline North Carolina & $15(\mathrm{R})$ & $2,189,322$ & $2,362,632$ & 48.10 & 51.90 & 7 & 8 \\
\hline Pennsylvania & $20(\mathrm{R})$ & $2,926,441$ & $2,970,733$ & 49.62 & 50.38 & 10 & 10 \\
\hline \multirow[t]{2}{*}{ Wisconsin } & $10(\mathrm{R})$ & $1,382,536$ & $1,405,284$ & 49.59 & 50.41 & 5 & 5 \\
\hline & & $16,688,782$ & $17,069,278$ & & & 60 & 61 \\
\hline
\end{tabular}

Notes: ${ }^{1}$ Hypothetical results. (R) stands for the Republican Party and (D) for the Democratic Party.

Sources: National Archives (2020); authors' own calculations.

\section{The biasing effect of the Electoral College}

In the 2016 presidential election, Donald Trump won the "swing states" of Michigan, Wisconsin and Pennsylvania by an extremely small margin of 77,744 votes. ${ }^{1}$ But, looking at the results in all 50 US states and the District of Columbia, Hilary Clinton won the total popular vote by $2,839,187$ votes over Trump. This means that a vote for Trump counted 36 times more than a vote for Clinton. This does not seem like a sign of a strong democracy.

Table 1 shows the result of the 2016 presidential election by state. With the exception of Maine, all the electors were chosen by "the-winner-takes-all" principle. The third and fourth columns present the absolute number of votes gained by Clinton and Trump respectively. The latter, as a matter of fact, gained (only) 62,955,212 votes against those $65,794,399$ of Clinton. The last two columns show the results according to the popular vote (share). Summing up the Electoral College reveals that Trump received 304 electoral college votes, while Clinton received only $227 .^{2}$

Two proposals for the correction of biasing effects in the Electoral College

\section{Scenario 1: The Maine/Nebraska principle}

In this first alternative scenario, the number of electors who are assigned to one (or the other) presidential

1 The exact percentage score was in Michigan: $50.12 \%$ (T) / 49.88\% (C), Wisconsin: $50.41 \%$ (T) / 49.59\% (C) and Pennsylvania: $50.38 \%$ (T) / $49.62 \%(C)$.

2 Notice that we do not report the results achieved by other parties. In California, for example, the Libertarian Party won 478,499 votes and the Green Party 278,657 votes. candidate will be determined solely by the popular vote share that the candidate achieves in the respective state. Hence, the proportionality principle displaces the majority principle and the winner-takes-all principle.

To make the difference clear, Table 2 first presents the original score in the elections of 2016, taking nine prominent states as an example. The reason for selecting these nine states in particular is that they have an interesting property in common: They all have a very close vote split, almost $51 \%$ to $49 \%$, between the two candidates. ${ }^{3}$ Clinton won the states of Minnesota, Nevada and New Hampshire and therefore (only) 20 electors; yet with a minimal margin, Trump won Arizona, Florida, Michigan, North Carolina, Pennsylvania and Wisconsin, which yielded 101 electors. But, if one looks at the absolute votes in this sample, the difference between Trump and Clinton amounted to only 380,596 . That is only $1.1 \%$ of $33,758,060(16,688,782$ plus $17,069,278)$. Nothing else could demonstrate to this extent the distortion created by the majority principle.

In the last two columns of Table 2, we calculate the distribution of electors between Clinton and Trump if the proportionality and not the majority principle would have been at work.

Extending the Nebraska-Maine or proportionality principle to all 50 US states and the District of Columbia, the final result would have handed Clinton the election with

3 In 2016, similar to many earlier elections for US Presidency, the turnout was slightly above $50 \%$. The percentages calculated here, hence, only apply to the distribution of effective votes between Clinton and Trump. 
269 electoral college votes to Trump's $262 .{ }^{4}$ As a consequence, she should have won the US presidential election in 2016. This outcome better mirrors her advantage of three percentage points in the popular vote share over Trump. ${ }^{5}$

\section{Scenario 2: Direct election of the president}

A direct election, applying the majority principle, is a widely used method, for example, for electing mayors. The winner is the candidate who receives more than half of the valid votes. This sort of battle is easy to organise given that it requires only the absolute number of votes from every state.

In 2016, Clinton would have clearly won according to this simple rule: She won $65,794,399$ direct votes whereas Trump received only 62,955,212.

\section{Gerrymandering is undermining representation}

In 2020, the decennial census was organised in all of the 50 US federal states. The information from the census is used by state legislatures and/or consulting commissions to redesign the existing voting districts for future elections of Members of the House of Representatives. The districts should, in principle, be compact, contiguous to each other and encompass the same size and structure as the population (Szikalai and Heberger, 2020). Past experience, however, shows that politicians often use redistricting for gerrymandering. ${ }^{6}$ For an illustration of how gerrymandering functions, we examine the example of the state of Wisconsin in 2016.

We depart from the simplifying assumption that there are two parties (no independents, voter turnout of 100\%) and a total of 24 incumbents. Thirteen of these vote for Democrats, 11 vote in favour of the Republican Party. Hence, in the popular vote, the Democrats win $54.2 \%$ of the vote share compared to the Republicans' $45.8 \%$. New districting regulations distribute these 24 incumbents over eight units of election. In Figure 1, these districts are depicted in a simplified interpretation - as eight vertical parallels: Districts 1 through 3 contain three Democratic voters only. Districts 4 through 7 contain one partisan of the Demo-

4 Notice that these two figures must add up to $531(269+262)$, as the factual electors won by Clinton and Trump were 227 and 304 respectively, totalling 531 .

5 When including "others" into the calculation, the score changes slightly, but still sees Clinton at the lead with 258 electors, Trump with 252 electors and 28 electors assigned to the "others". See Ahsan (2020).

6 This term originates from the former governor of Massachusetts in 1812, Elbridge Gerry. Almost artistically, his fantasy led him to create districts that resembled a salamander (Illinger et al., 2018) with the clear purpose of securing his re-election.
Figure 1

Gerrymandering in Wisconsin, 2016

\begin{tabular}{|l|l|l|l|l|l|l|l|}
$D$ & D & D & R & R & R & R & R \\
D & D & D & D & D & D & D & R \\
D & D & D & R & R & R & R & R
\end{tabular}

Notes: The real districts of Wisconsin look much more like a salamander. $R$ stands for the Republican Party and D for the Democratic Party.

Source: Authors' own compilation.

crat Party and two partisans of the Republican Party. District 8 contains three partisans of the Republican Party only. As we can easily discern, the Democrats (Republicans) win three (five) out of eight districts and hence send fewer (more) representatives to Congress. This is equivalent to a "seat share" of $37.5 \%(62.5 \%)$. It is understood that the "seat share" does not fairly represent the "vote share" (see above). This scenario mirrors almost exactly the situation of the state of Wisconsin in the electoral year 2016 , and it is a strong example of active gerrymandering.

The Republicans won five districts (4-8), giving in with respect to the first three districts. Here, the Democrats have a win of $100 \%$ in each. This is what is called in literature "packing and cracking" (Konishi and Pan, 2020): give the opponents a large majority in a minority of districts ("packing") and focus on securing a majority in the districts with the lowest margin at hand ("cracking"). As a result, Republicans (Democrats) win five (three) out of eight districts for a "seat share" of $62.5 \%$ (37.5\%), although their popular vote share is much lower (45.8\%) compared to the Democrats $(54.2 \%)$ and, of course, the minority (majority).

How can this unfair districting system be corrected? $\mathrm{Bi}-$ erbrauer and Polborn (2020) have a suggestion rooted in sub-game perfect solutions of non-cooperative game theory. Each party is invited to appoint party supporters in a round-by-round process and delegate them to the different districts until the total number of supporters (from both parties) is exhausted. The dynamics of action and reaction are meant to let both parties neutralise each other. Each party is allowed a number of supporters according to their popular vote share. The party that begins has, in principle, a so-called first mover disadvantage, because it cannot react to the opponent's last move. This strategy is illustrated in Figure 2.

Notice that the Democrats use their first move to delegate one partisan to each district (1-8). Thereby, they "consume" eight of their 13 partisans. In the second stage, Republicans do the same and consume also eight of their 11 partisans. In the third stage, Democrats delegate their remaining five partisans; Republicans follow 
Figure 2

Correcting for gerrymandering in Wisconsin, 2016

\begin{tabular}{|l|l|l|l|l|l|l|l|}
$D$ & $D$ & $D$ & $D$ & $D$ & $D$ & $D$ & $D$ \\
$R$ & $R$ & $R$ & $R$ & $R$ & $R$ & $R$ & $R$ \\
$D$ & $D$ & $D$ & $D$ & $D$ & $R$ & $R$ & $R$
\end{tabular}

Note: $R$ stands for the Republican Party and D for the Democratic Party.

Source: Authors' own compilation.

and finish the game with the delegation of their last three partisans. What is the result? Democrats (Republicans) win five (three) of the eight districts, so their seat share is now $62.5 \%$ (37.5\%), which comes much closer to the vote share of $54.2 \%$ (45.8\%). Moreover, the sequencing in the score of the parties is now correct: Democrats beat Republicans both in the vote share and in the seat share.

If one is still unsatisfied with this result, have a look at the alternatives: the seat shares might be $75 \%$ vs. $25 \%$ (with six seats for the Democrats and two for the Republicans). This would be too unrepresentative of the vote share $(54.2 \%$ vs. $45.8 \%$ ). If Democrats (Republicans) win four (four) of the eight districts, the seat shares would be split 50/50, resulting in a draw, which would violate the majority principle. Although intellectually appealing, Bierbrauer and Polborn's (2020) concept suffers from one fundamental deficit: Noncooperative game theory can hardly deliver political feasibility. What is needed here seems to be a coalition in favour of fairness and democracy. Coalition of whom? In the best case scenario, it would be a coalition of all individuals affected by the consequences of (biased) elections.

\section{A proposal for the internalisation of (external) gerrymandering effects}

Public finance, as an essential part of economic theory, is primarily dedicated to the role of government in providing public goods to the private sector. Whenever individuals are being affected (whether positively or negatively) by actions of other economic agents, this issue is investigated under the label "external effects" (e.g. Luckenbach, 2000; Ribhegge, 2007) and the possible strategies for their internalisation. Experts speak of "non-pecuniary, technological external effects" (Luckenbach, 2000, 146): Activities in consumption and/or in production of one group of agents have a negative (social costs) or positive (social benefits) effect on the activity (in consumption and/or in production) level of another group of agents. This mechanism should not be confounded with (monetary) spill-over effects stemming from ordinary market processes, where rising or falling prices due to demand or supply shifts are a natural outcome of new relevant information or expectations.
It is then the obligation of economic policy to design internalisation strategies to reduce (raise) external costs (benefits). Kirsch (2004, 31-33), one of the most respected representatives of the school of political economy, has developed a smart mechanism for the internalisation of external costs: all those individuals who would suffer (or enjoy) the consequences of a decision should participate in the decision-making process itself. The idea is, generally speaking, to involve those who are directly affected by an issue.

Gerrymandering, in a sense, is comparable to the occurrence of external costs: The voters whose weight in the vote share is not reflected sufficiently in the seat share as a consequence of the partisan districting policy of either Democrats or Republicans are affected negatively. This was the case of Wisconsin - pars pro toto - as shown above.

There already exists some sort of model for the idea of Kirsch in reality. In some of the affected states, we find "redistricting commissions" that either come up with their own suggestions for the legislation or otherwise function during the process of redesign as consulting/advisory agencies. "Participating clauses" - beyond the existing "compactness clauses" for the design of districts - should be established, if they have not been already. Herewith, a large number of stakeholders in the process of elections to the House of Representatives would come into play. It goes without saying that these stakeholders must include not only bipartisans and partisans, but also independents (Bierbrauer and Polborn, 2020). Therefore, the practised system in California and lowa, where so-called non-partisan districting committees act in an advisory role, is a good starting point but not the final solution (Konishi and Pan, 2020, 1185).

In essence, the concept of Kirsch (2004) develops further what Dudenhöffer $(1984,190)$ already claimed in his remarkable $\mathrm{PhD}$ thesis: Consumers should be given the right to decide upon issues regarding the usage of the public good "environment". Substituting "consumers" for "voters" and "environment" for "democracy" underlines this analogy.

\section{Strengthening democracy in Europe}

What sort of implications do the challenges facing American democracy have for Europe? Are there parallels in Europe? In the first place, one has to distinguish between parallels to Trumpism vs. parallels with problems facing the US electoral system.

Poland and Hungary nowadays have political leaders who are "affine" to the pitfalls of Trumpist populism. The EU Commission continuously asks them to respect the rule of law, the acquis communautaire and the independence 
of the traditional democratic powers in their country (judicial, legislative and executive). In a way, one sees the Trump era mirrored in some EU countries. There are fears that they could follow suit. If Europe has learned anything from the Trump era, it is that it is better in international affairs to have a Plan B of your own when your former "partner" is on a "my-country-first" trip.

What about the transparency and credibility of democracy in Europe? These two issues are not independent of each other: Transparency is a means to achieve credibility. Progress has been made with regard to the role of the European Parliament in the appointment process of (the head of) the EU Commission. The incumbent in EU member states now seems to better recognise the different existing political streams and groups. Hence, transparency of the voting process has been increased. The same applies to the Governing Council of the European Central Bank (ECB), ever since it agreed to publish the protocols of their sessions and thereby improve the transparency of its decision-making process. But there is still no final consensus about the criteria for the determination of "country shares" (number of seats by country) in the European Parliament itself. The public should be better acquainted with the different positions and their respective costs and benefits. European institutions, like the European Council or the Governing Council of the ECB, follow strict majority (if not unanimity) rules when it comes to making economic and monetary policy decisions. At least in the case of the ECB, it is still a controversial issue whether countries like Malta or Cyprus should have the same voting power as Germany, Italy or France.

Redistricting may become an issue during the reform of the electoral system in Germany, given the fact that the federal German parliament, the German Bundestag in Berlin, has become "too crowded". One idea is to build fewer, but larger voting districts. A commission of partisans, bipartisans and independents should help to avoid gerrymandering effects.

\section{Conclusions and the scope for future research}

Only a few years ago, it was a widespread belief that globalisation would trigger processes of democratisation worldwide. The Arab Spring, which began in Tunisia in late 2010, was only one of the deceptions experienced. Moreover, it appears that even old and seemingly established models of democracy, as the one installed in the United States, came under fire. However, it is not less but more democracy that is needed.

In this article, we recommend profound and transparent Electoral College reforms in the election of US presidents. Using the presidential election of 2016 as an example, a thorough analysis of the results reveals that the actual voting system - de facto a mix of the majority principle with indirect democracy - is heavily distorted. A candidate, like Clinton in 2016, may win in the popular vote by a margin of three percentage points and may still be defeated in the Electoral College - which is what counts.

We have put forward two alternative reform proposals to overcome these deficits: One scenario retains "indirect democracy" for the election of the US President by the members of the Electoral College, but strictly links the appointment of the latter to the proportionality principle. The second scenario makes the election of the US President an issue of direct democracy, applying the majority principle. Both scenarios, in our view, do better than the actual election system. They foremost fulfil the criteria of transparency and feasibility.

We also found serious problems with the current gerrymandering policy, i.e. the redesign of new voting districts every 10 years. The results of elections to the House of Representatives are very distorted by this procedure. Reform discussion is under way, and this article puts forward ideas about how to include and integrate the most important stakeholders.

There are more discussions on this issue that are not touched upon in this paper. One refers to the US Senate. This important parliamentarian body of the US Congress is under scrutiny, too. It is worthwhile to think about the following: The US Senate could also hold elections every four years, simultaneously with the presidential elections. By doing so, it would ensure that every elected president is able to rely on majorities in both Houses of the Congress, thereby making presidential reform agendas and projects that have a higher probability of being enacted. And this is precisely what the incumbent expects from pure or hybrid systems of direct democracy.

\section{References}

Ahsan, S. M. (2020), The Idea of Jurisdictional Representation in a Federation: A Proposal and Illustrations from Recent Canadian and US Elections, CESifo Working Paper Series, 8676.

Bierbrauer, F. J. and M. Polborn (2020), Competitive Gerrymandering and the Popular Vote, ECONtribute Discussion Paper, 034.

Dudenhöffer, F. (1984), Mehrheitswahlentscheidungen über Umweltnutzungen: Eine Untersuchung von Gleichgewichtszuständen in einem mikroökonomischen Markt- und Abstimmungsmodell, Peter Lang.

National Archives (2020), Electoral College Results, https://www.archives.gov/electoral-college (18 January 2021).

Illinger, P., C. Endt and J. Hosse (2018, 2 February), Wie die USA ihre Demokratie zerschneiden, Süddeutsche Zeitung.

Kirsch, G. (2004), Neue Politische Ökonomie, 5th edition, Lucius \& Lucius. Konishi, H. and C.-J. Pan (2018), Partisan and bipartisan gerrymandering, Journal of Public Economic Theory, 22(5), 1183-1212.

Luckenbach, H. (2000), Theoretische Grundlagen der Wirtschaftspolitik, 2nd edition, Vahlen.

Ribhegge, H. (2007), Europäische Wirtschafts- und Sozialpolitik, Springer.

Szikalai, B. R. and K. Heberger (2020), Apportionment and Districting by Sum of Ranking Differences, CERS-IE Working Paper, 9/2020. 